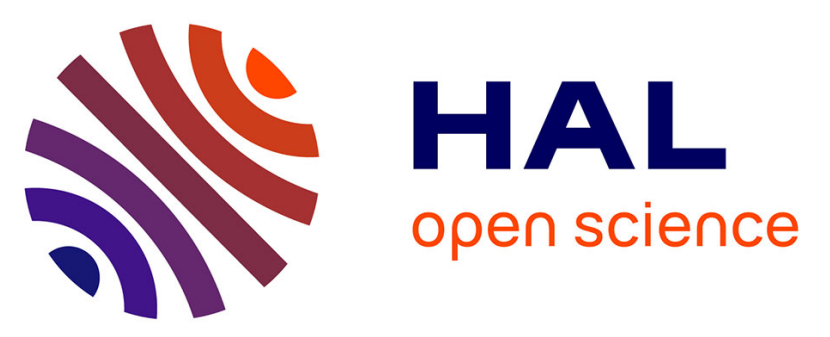

\title{
Planar Chiral Phosphoric Acids with Biphenylene-Tethered Paracyclophane Scaffolds: Synthesis, Characterization, and Catalytic Screening
}

Kevin Isaac, Jérémy Stemper, Vincent Servajean, Pascal Retailleau, Julien Pastor, Gilles Frison, Karl Kaupmees, Ivo Leito, Jean-François Betzer, Angela Marinetti

\section{To cite this version:}

Kevin Isaac, Jérémy Stemper, Vincent Servajean, Pascal Retailleau, Julien Pastor, et al.. Planar Chiral Phosphoric Acids with Biphenylene-Tethered Paracyclophane Scaffolds: Synthesis, Characterization, and Catalytic Screening. Journal of Organic Chemistry, 2014, 79 (20), pp.9639-9646. 10.1021/jo501769t . hal-02152303

\section{HAL Id: hal-02152303 https://hal.science/hal-02152303}

Submitted on 20 Sep 2019

HAL is a multi-disciplinary open access archive for the deposit and dissemination of scientific research documents, whether they are published or not. The documents may come from teaching and research institutions in France or abroad, or from public or private research centers.
L'archive ouverte pluridisciplinaire HAL, est destinée au dépôt et à la diffusion de documents scientifiques de niveau recherche, publiés ou non, émanant des établissements d'enseignement et de recherche français ou étrangers, des laboratoires publics ou privés. 


\title{
Planar Chiral Phosphoric Acids With Biphenylene-tethered Paracyclophane Scaffolds: Synthesis, Characterization and Catalytic Screening
}

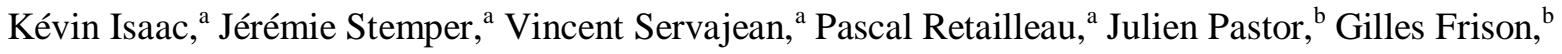 \\ Karl Kaupmees, ${ }^{\mathrm{c}}$ Ivo Leito, ${ }^{\mathrm{c}}$ Jean-François Betzer, ${ }^{* a}$ and Angela Marinetti*a \\ ${ }^{\text {a }}$ Institut de Chimie des Substances Naturelles, CNRS UPR 2301, 91198 Gif-sur-Yvette, France \\ ${ }^{\mathrm{b}}$ Laboratoire de Chimie Moléculaire, Ecole Polytechnique and CNRS, UMR 9168, 91128 Palaiseau \\ Cedex, France \\ ${ }^{\mathrm{c}}$ Institute of Chemistry, University of Tartu, 14 Ravila Street, 50411 Tartu, Estonia
}

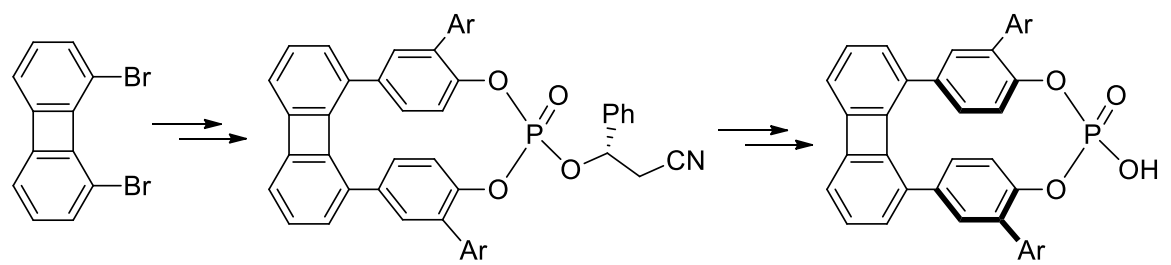

ABSTRACT: Phosphoric acids with planar chiral paracyclophane scaffolds have been prepared in optically pure form starting from 1,8-dibromobiphenylene, by means of a chiral phosphorodiamidate as the phosphorylating agent. Structural characterization and configurational assignment have been performed by X-ray diffraction studies. The acids promote the organocatalytic enantioselective $\mathrm{H}$ transfer reduction of $\alpha$-arylquinolines with up to $90 \%$ enantiomeric excess.

\section{Introduction}

The widespread uses of phosphoric acids and phosphates as chiral acids, ${ }^{1}$ chiral anions and ligands ${ }^{2}$ are among the major achievements of modern enantioselective catalysis. In this field, the atropochiral Binol derived phosphoric acids are privileged auxiliaries, but alternative scaffolds have also been developed, including Spinol $^{3}$ and Taddol $^{4}$ derivatives, which display axially chiral structures and stereogenic carbons respectively.(For recent references, see: ${ }^{5}$ ) The above series of chiral phosphoric acids might be suitably complemented by analogous derivatives exploiting planar chiral scaffolds. In this context, having noticed that a single example of planar chiral phosphoric acids had been reported, ${ }^{6}$ we have initiated a research project oriented toward the development of phosphoric acids of this class. In our previous papers ${ }^{7}$ we have disclosed the first series of planar chiral phosphoric acids represented hereafter by the general formula 1 (Figure 1).

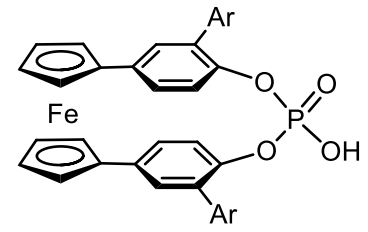

1

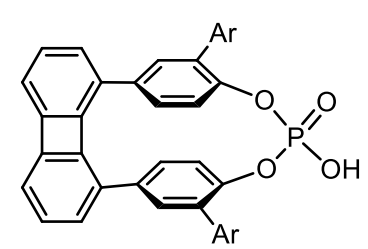

2 (this work)

Figure 1. Planar chiral phosphoric acids based on paracyclophane scaffolds.

They are paracyclophanes with a 1,1'-ferrocendiyl and an O-P-O units tethering the aromatic rings in their para-positions. Two aryl substituents (Ar) generate the desired planar chirality while giving a formally C2-symmetric scaffold. The 1,1'-ferrocendiyl unit had been targeted initially as a suitable linker, based on DFT studies showing that it will give moderate ring strain, combined with satisfying 
configurational stability of the paracyclophane. Acids $\mathbf{1}$ proved to be good catalysts for the enantioselective $\mathrm{H}$-transfer reduction of 2 -substituted quinolines (e.e. up to $92 \%$ ). They displayed however an only moderate thermal stability, giving an estimated $10 \%$ decomposition rate after $18 \mathrm{~h}$ heating at $60^{\circ} \mathrm{C}$. Their uses will be therefore reasonably restricted to catalytic reactions taking place at room temperature or lower. To hopefully overcome this limitation, we have turned then our attention to analogous paracyclophane-type derivatives bearing different tethering chains. This paper reports on our studies oriented toward this goal and especially toward the use of a biphenylen-1,8-diyl unit as the tethering chain, as typified by compound $\mathbf{2}$ in Figure $\mathbf{1}$.

\section{Results and Discussions}

In this work, with the aim of accessing new phosphoric acids with paracyclophane structures, we have envisioned the biphenylen-1,8-diyl unit as a possible paracyclophane tethering chain. Compared to the previously used 1,1'-ferrocendiyl motif of $\mathbf{1}$, the four atom biphenylene tether is anticipated to give slightly longer $\mathrm{C}-\mathrm{C}$ distances between the aromatic rings of the paracyclophane: $a$ and $b$ distances have been calculated indeed at 3.76 and $3.13 \AA$ respectively for 2' vs. 3.51 and $3.09 \AA$ for 1', at the M06/6-31G(d,p) DFT level (Figure 2). The ring strain energy has been calculated ${ }^{8}$ however to be slightly higher for 2' with respect to $\mathbf{1}^{\prime}(24 \mathrm{~kJ} / \mathrm{mol}$ vs $17 \mathrm{~kJ} / \mathrm{mol})$, which is likely related to the rigidity of the biphenylene structure, compared to the flexible ferrocene scaffold. The activation energy required for the rotation of the aromatic ring around the C- - -O axis $\left(\Delta \mathrm{G}^{\neq}\right.$in Figure 2) has been calculated at $180 \mathrm{~kJ} / \mathrm{mol}$ for $\mathbf{2}$ ', i.e. slightly lower than for the ferrocenic derivative $\mathbf{1}$ ' $(216 \mathrm{~kJ} / \mathrm{mol})$, but still high enough to likely ensure the configurational stability of the molecule.

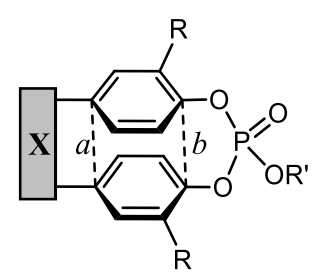

$$
\begin{gathered}
\text { 1': } \mathrm{X}=\text { ferrocen-1,1'-diyl } \\
\mathrm{R}=\mathrm{H}, \mathrm{R}^{\prime}=\mathrm{H} \\
\text { 1a: } \mathrm{X}=\text { ferrocen-1,1'-diyl } \\
\mathrm{R}=4-\mathrm{Ph}^{-} \mathrm{C}_{6} \mathrm{H}_{4} \\
\mathrm{R}^{\prime}=\mathrm{OCH}(\mathrm{Ph}) \mathrm{CN} \\
\text { 1b: } \mathrm{X}=\text { ferrocen-1,1'-diyl } \\
\mathrm{R}=\mathrm{Ph}, \mathrm{R}^{\prime}=\mathrm{OCa} \\
\text { 2': } \mathrm{X}=\text { biphenylen-1,8-diyl } \\
\mathrm{R}=\mathrm{H}, \mathrm{R}^{\prime}=\mathrm{H}
\end{gathered}
$$

\begin{tabular}{|c|c|c|c|}
\hline & $a(\AA)$ & $b(\AA)$ & $\Delta \mathrm{G}^{\neq}$ \\
\hline \multicolumn{4}{|l|}{ Ferrocen-1,1'-diyl derived paracyclophanes, 1} \\
\hline Calculated values for $\mathbf{1}$ & 3.51 & 3.09 & $216 \mathrm{~kJ} / \mathrm{mol}$ \\
\hline Experimental values for $\mathbf{1 a}^{7 \mathrm{~b}}$ & 3.495 & 3.099 & \\
\hline Experimental values for $\mathbf{1 b}^{7 \mathrm{~b}}$ & 3.404 & 3.022 & \\
\hline \multicolumn{4}{|l|}{ Biphenylen-1,8-diyl derived paracyclophanes, 2} \\
\hline Calculated values for $\mathbf{2}$ & 3.76 & 3.13 & $180 \mathrm{~kJ} / \mathrm{mol}$ \\
\hline
\end{tabular}

\section{Rotation process for which $\Delta \mathrm{G}^{\neq}$ values have been calculated:}

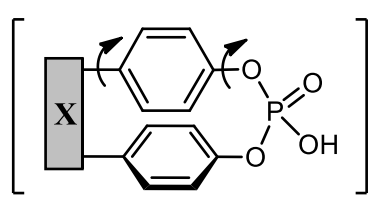

Figure 2. Calculated/experimental structural parameters and rotation barriers for paracyclophane-type phosphoric acids $\mathbf{1}$ and $\mathbf{2}$

Based on these rather encouraging calculation results, we have investigated then synthetic approaches to acids $\mathbf{2}$. To this end, we have adapted the strategy previously used for the synthesis of $\mathbf{1}$, which made use of two sequential Suzuki couplings to create both the ferrocene-aryl and the aryl-aryl bonds. ${ }^{7 \mathrm{~b}}$ When applied to the synthesis of $\mathbf{2}$, the method involves 1,8 -dibromobiphenylene $\mathbf{3}$ as the starting material, and the two Suzuki coupling steps shown in Scheme $\mathbf{1}$ and 2. The bis-boronate 6, diol $\mathbf{8}$ and the chiral phosphates $\mathbf{1 0}$ in Scheme 3 are the key intermediates. 


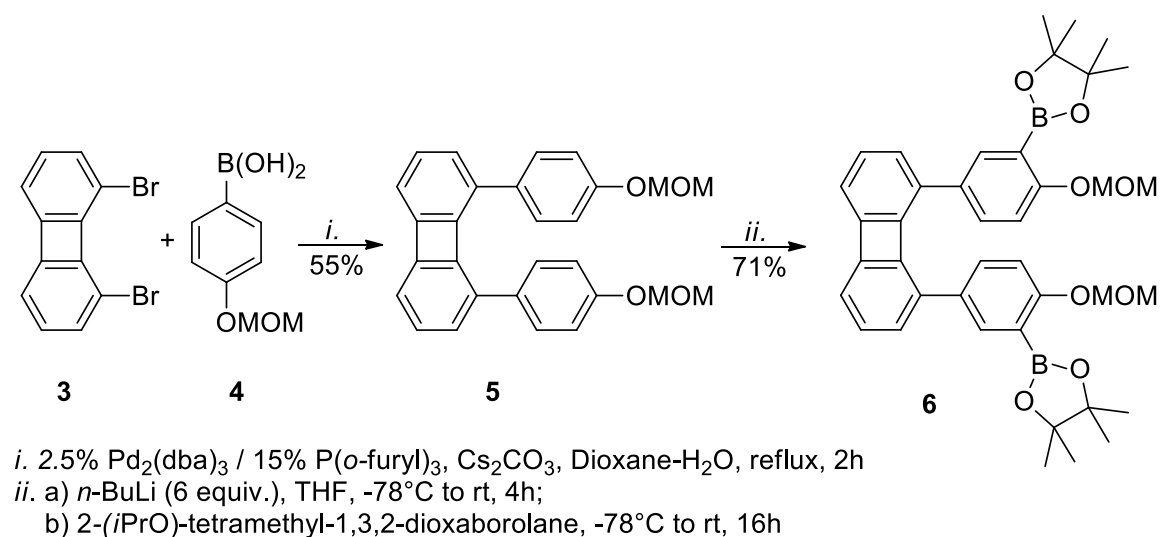

Scheme 1. Synthesis of the bis-boronate 6

The synthetic procedure starts with a Suzuki coupling between 1,8-dibromobiphenylene, $\mathbf{3},{ }^{9}$ and the aryl-boronic acid $\mathbf{4}^{10}$ which displays a MOM-protected hydroxyl function in its para-position. The reaction takes place in a dioxane-water mixture, in the presence of a $2.5 \mathrm{~mol} \%$ amount of $\mathrm{Pd}_{2}(\mathrm{dba})_{3}$ and $15 \mathrm{~mol} \%$ of tri( $o$-furyl)phosphine. The desired product 5 has been isolated in $55 \%$ yield at a $17 \mathrm{~g}$ scale. Other catalysts and conditions previously reported for the double arylation of $\mathbf{3}$ (e.g. $\left.\mathrm{Pd}\left(\mathrm{PPh}_{3}\right)_{4}\right)^{11}$ did not afford improved yields.

Compound 5 has been converted then into the corresponding bis-boronate 6 by a metalation-borylation reaction ${ }^{12}$ taking advantage from the ortho-directing effect of the O-MOM functions: addition of an excess $n$-BuLi to $\mathbf{5}$ in THF, afforded the dilithiated derivative which was trapped then with isopropyl pinacolborate. The bis-boronate $\mathbf{6}$ has been isolated in $71 \%$ yield at a $19 \mathrm{~g}$ scale.

As demonstrated in our previous work on the analogous series of ferrocene-derived paracyclophanes 1, this compound should represent a useful platform for the introduction of various substituents on the aryl rings by coupling reactions. This step has been illustrated here by the synthesis of the highly hindered meta-terphenyl-substituted diol 8 by palladium-catalyzed Suzuki coupling, under $\operatorname{Pd}\left(\mathrm{PPh}_{3}\right)_{4}$ catalysis (Scheme 2).

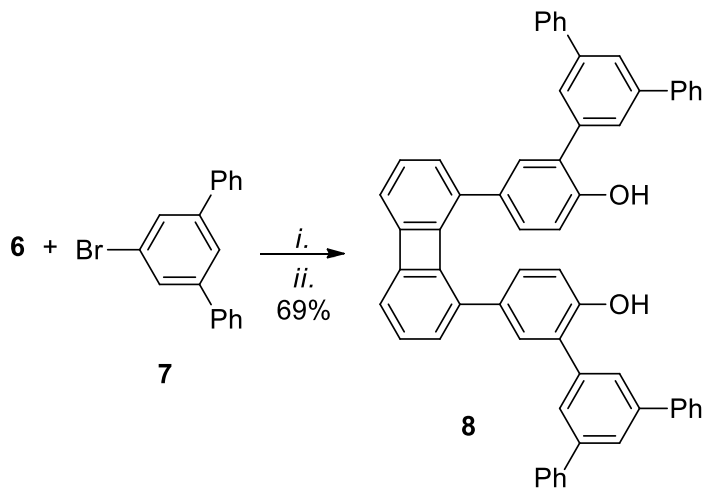

i. $5 \% \mathrm{Pd}\left(\mathrm{PPh}_{3}\right)_{4}, \mathrm{DME}, \mathrm{Cs}_{2} \mathrm{CO}_{3}, \mathrm{Ba}(\mathrm{OH})_{2} \cdot 8 \mathrm{H}_{2} \mathrm{O}$, reflux, $18 \mathrm{~h}$ ii. $\mathrm{HCl}_{\mathrm{aq}}$, dioxane- $\mathrm{MeOH}, 60^{\circ} \mathrm{C}, 4 \mathrm{~h}$

Scheme 2. Synthesis of diol 8

After in situ removal of the MOM protecting groups from the intermediate coupling product, the desired diol 8 has been isolated in $69 \%$ yield. The ${ }^{1} \mathrm{H}$ and ${ }^{13} \mathrm{C}$ NMR spectra of $\mathbf{8}$ show single sets of signals that reveal unhindered rotation of the aryl substituents of the biphenylene unit.

The synthesis of the desired phosphoric acid in optically pure form has been carried out then by reacting diol $\mathbf{8}$ with the chiral phosphinating agent 9, according to our recently established procedure $^{7 \mathrm{~b}, 13}$ (Scheme 3). The cyclization reaction of diol $\mathbf{8}$ with phosphoramidite $\mathbf{9}$ in the presence 
of $1 H$-tetrazole, followed by oxidation of the resulting phosphites with tert-butylhydroperoxide, afforded a 7:3 mixture of the corresponding cyclic phosphates 10a and 10b. In principle, the cyclization reaction might afford also the third isomer with non-chiral configuration of the paracyclophane scaffold, in which the two aryl substituents would be located on the same face of the paracyclophane. This isomer has not been detected in the reaction mixture. Phosphates 10a,b have been obtained in high, $86 \%$ yield over two steps. The cyclization step takes place here in much better yield than the analogous cyclization leading to the ferrocenic acids 1 ( $86 \%$ vs $40 \%$ ). This undoubtedly relates to the rigid biphenylene unit, which forces the aromatic rings of $\mathbf{8}$ in a suitable, almost parallel arrangement.

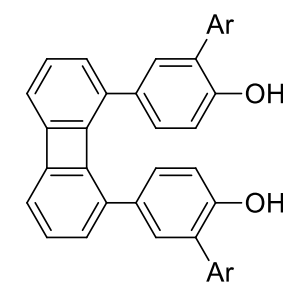

8, $\mathrm{Ar}=m$-terphenyl

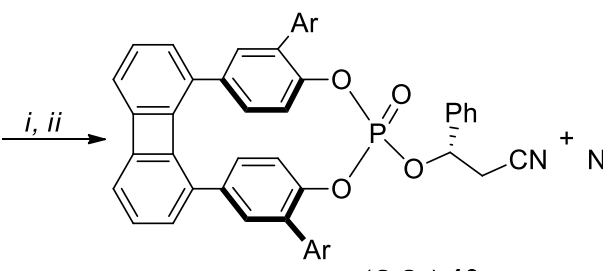

$\left(S, S_{P}\right)-10 a$

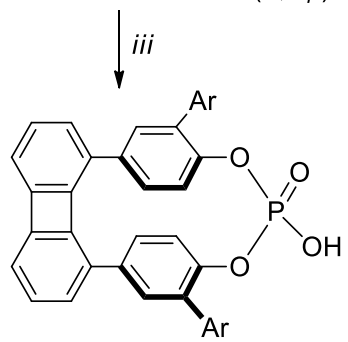

$(+)-(S)-2 a$

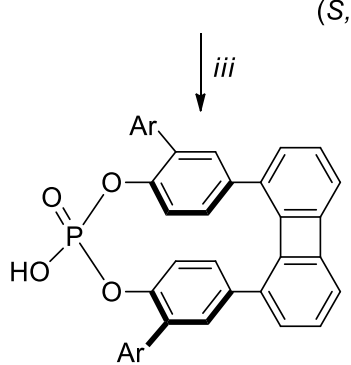

$(-)-(R)-2 a$

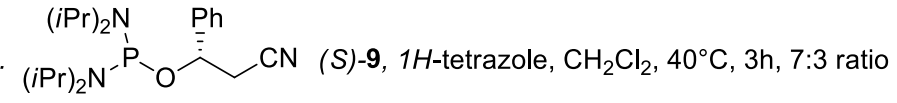

ii. $\mathrm{tBuOOH}, \mathrm{CH}_{2} \mathrm{Cl}_{2}, 0^{\circ} \mathrm{C}, 30 \mathrm{~min}, 86 \%$; iii. $\mathrm{DBU}, \mathrm{CH}_{2} \mathrm{Cl}_{2}, \mathrm{rt}, 30 \mathrm{~min}, 86-92 \%$
}

Scheme 3. Synthesis of the planar chiral phosphoric acids (+)-2a and (-)-2a

The two epimers of $\mathbf{1 0}$ could be separated easily by semi-preparative HPLC (NW50 silica gel column, heptane/toluene/THF 4/95/1, retention times: $10.0 \mathrm{~min}$ for $\left(S, S_{P}\right)-\mathbf{1 0 a}\left([\alpha]_{\mathrm{D}}=+68\left(\mathrm{c}=1, \mathrm{CHCl}_{3}\right)\right)$ and 13.0 min for $\left(S, R_{P}\right)-\mathbf{1 0 b}\left([\alpha]_{\mathrm{D}}=-123\left(\mathrm{c}=1, \mathrm{CHCl}_{3}\right)\right)$ and fully characterized. Thus, although the chiral auxiliary $(S)-9$ induced an only moderate diastereoselectivity in this cyclization reaction, HPLC separation of the epimers afforded synthetically useful amounts of the pure compounds $\mathbf{1 0 a}$ and $\mathbf{1 0 b}$.

The configuration of the epimeric paracyclophanes has been assigned from the X-ray crystal structure of 10a shown in Figure 3 (CCDC 1014151). This epimer displays an $S_{P}$ configuration (relative configuration with respect to the known (S)-configuration of the chiral auxiliary). ${ }^{14}$ The structural parameters of $\left(S, S_{P}\right)$-10a from X-ray data are in good agreement with the calculated parameters in Figure 2. Notably the key non-bonding $a$ and $b$ distances which define the paracyclophane geometry and modulate the ring strain, have been measured at $3.794 \AA$ and $3.197 \AA$ respectively, vs $3.76 \AA$ and $3.13 \AA$ for calculated values. With respect to the analogous ferrocene tethered paracyclophane 1a, the larger macrocyclic ring of 10a generates a slightly larger O-P-O intracyclic bond angle $\left(106.89^{\circ}\right.$ for 10a, vs $105.76^{\circ}$ for phosphate $\mathbf{1 a}^{7 \mathrm{~b}}$ ), while the P-O distances measure about $1.60 \AA$ in both series. 

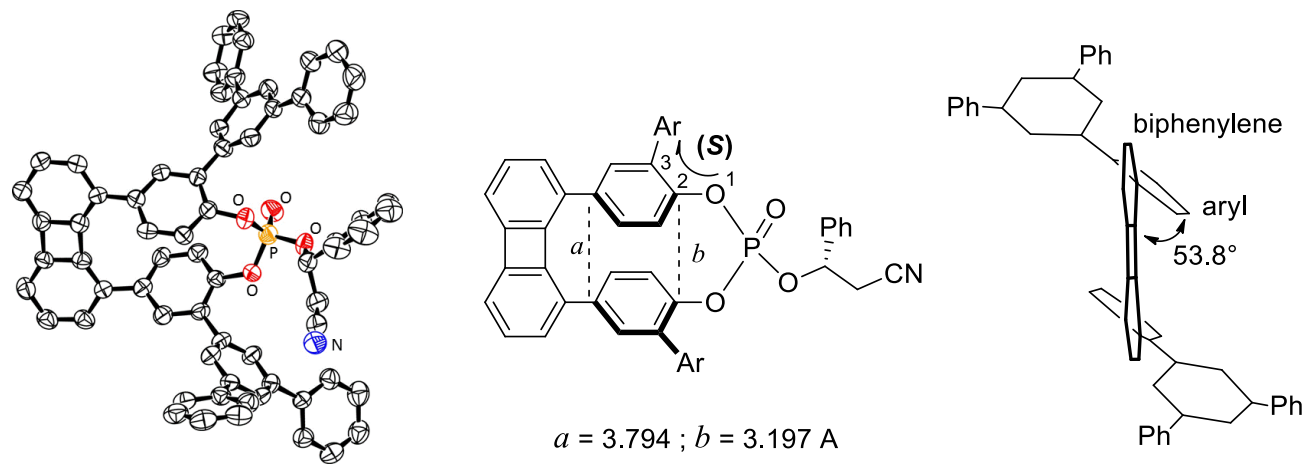

Figure 3. X-ray crystal structure of $\left(S, S_{P}\right)-\mathbf{1 0 a}$, stereochemical descriptor and key geometrical features.

X-ray data highlight significantly different geometrical features for the ferrocene based paracyclophane 1a and the biphenylene analogue 10a, with respect to their three-dimensional structure, in the solid state at least. Indeed, in phosphate $\left(S, S_{P}\right)$-10a the dihedral angle between the parallel aryl planes and the biphenylene-tether plane measures $53.8^{\circ}$, while in the ferrocene-based paracyclophane 1a the parallel aryl planes are almost orthogonal to the median plane of the ferrocene tether $\left(83.03^{\circ}\right.$ dihedral angle). The observed differences in the geometrical features are anticipated to cause slightly different catalytic behaviors for the two series of paracyclophanic acids, $\mathbf{1}$ and $\mathbf{2}$.

As shown in Scheme 3, phosphates $\left(S, S_{P}\right)$-10a and $\left(S, R_{P}\right)-\mathbf{1 0 b}$ have been converted into the desired phosphoric acids $(+)-(S)-\mathbf{2 a}\left([\alpha]_{\mathrm{D}}=+90\left(c=0.5, \mathrm{CHCl}_{3}\right)\right)$ and $(-)-(R)-\mathbf{2 a}$ respectively, by removal of the 1-phenyl-2-cyanoethyl substituent in the presence of DBU and subsequent washing of the resulting DBU-phosphate with an $\mathrm{HCl} 6 \mathrm{~N}$ solution. The acids have been obtained in $86-92 \%$ yields at a $1 \mathrm{~g}$ to 2 g scale, as colorless solids. The enantiomeric purity of these acids has been established by HPLC on an ID column with heptane/THF/TFA/Et ${ }_{3} \mathrm{~N}(40: 60: 0.5: 0.3)$ as the eluent: retention times 3.9 and 5.9 $\min ($ ee $>98 \%)$.

In order to ascertain the configurational stability of the biphenylene-based [4.3]-paracyclophane scaffold of 2a, we have heated a sample of acid $(S)-\mathbf{2 a}\left(>98 \%\right.$ ee) at $110^{\circ} \mathrm{C}$ in toluene. Chiral HPLC analysis didn't show any epimerization after heating for $16 \mathrm{~h}$. The sample did not show significant decomposition either, so that the experiment also demonstrates that acid 2a is chemically more stable than the ferrocene-based acids 1 which start to decompose at about $60^{\circ} \mathrm{C}^{7 \mathrm{~b}}$ Thus, the biphenylene based acid 2a has the potential of overcoming the limitations of the ferrocene-based acids in terms of thermal stability, while overall retaining the same key structural features related to planar chirality.

For comparison purposes, pKa values have been measured for the biphenylene derived acid $\mathbf{2 a}$ and the ferrocene-derived acid $\mathbf{1 c}$. 
(a)
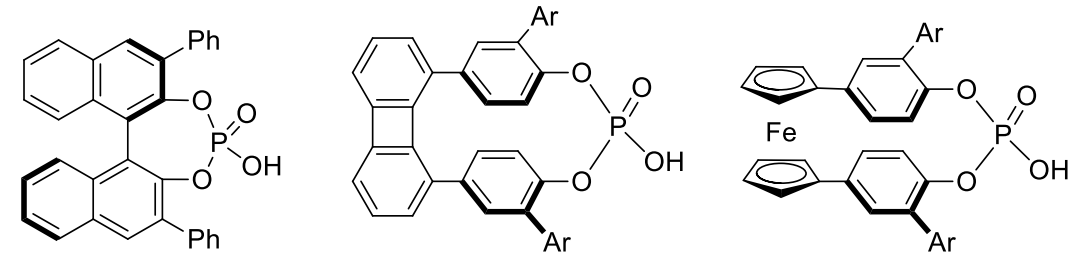

$\mathrm{pKa}=12.7(\mathrm{MeCN})$

2a, $\mathrm{pKa}=13.3(\mathrm{MeCN})$

1c, $\mathrm{pKa}=13.9(\mathrm{MeCN})$

acidity

(b)

$\mathrm{pKa}=6.4(\mathrm{MeCN})$

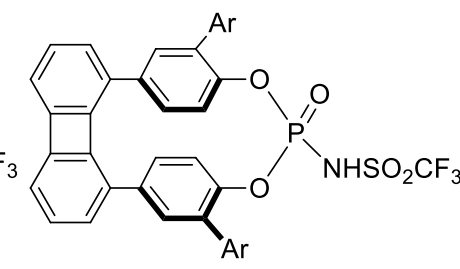

$11, \mathrm{pKa}=6.5(\mathrm{MeCN})$

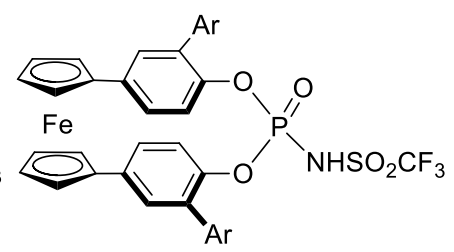

12, $\mathrm{pKa}=7.0(\mathrm{MeCN})$

$\mathrm{Ar}=m$-terphenyl

Figure 4. (a) pKa values for the phosphoric acids $2 \mathbf{2 a}, \mathbf{1 c}$ and a representative binol-derived acid; ${ }^{15}$ (b) pKa values for the corresponding sulfonimides

The pKa values have been obtained in $\mathrm{MeCN}$, according to the published procedure. ${ }^{15}$ With a pKa value of 13.3, the biphenylene derived acid 2a is slightly more acidic than the ferrocenic acid $\mathbf{1 c}$ (pKa $=13.9$ ), both of them being less acidic than the 3,3'-diphenyl-1,1'-binol derived phosphoric acid (pKa $=12.7$ ) (Figure 4). As expected, the pKa values remain however in the same range.

A decrease of the acidic character is observed also, although at a lower degree, in the mixed phosphoric-sulfonic imides, when going from Binol derived imides $(\mathrm{pKa}=6.4)$ to paracyclophanic imides with biphenylene $(\mathbf{1 1}, \mathrm{pKa}=6.5)$ and ferrocene tethers $(\mathbf{1 2}, \mathrm{pKa}=7.0) .{ }^{16}$ The lower sensitivity of pKa values towards structural changes in the imides series is reasonably expected, since most of the negative charge in the corresponding anions is delocalized on the strongly electron-withdrawing triflyl group. Structural changes in the remaining part of the molecule should have only minor effects on $\mathrm{pKa}$ values.

The last step of this study has been to validate the catalytic efficiency of the newly designed acid 2a by preliminary screenings in a model reaction, i.e. the organocatalytic $\mathrm{H}$-transfer hydrogenation of the $\alpha$-arylquinolines $\mathbf{1 3}$ with Hantsch esters. ${ }^{17}$ Results are shown in Table 1.

Table 1. Enantioselective H-transfer hydrogenation of $\alpha$-arylquinolines

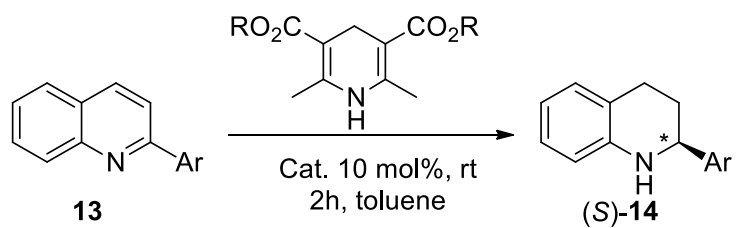

\begin{tabular}{|c|c|c|c|c|c|c|}
\hline entry & Substrate $^{\mathrm{a}}$ & $\mathrm{Ar}$ & Cat. & $\mathrm{R}$ (Hantsch ester) & Product & ee \\
\hline 1 & 13a & $\mathrm{Ph}$ & $(S)-\mathbf{2 a}$ & Et & $14 a$ & $77 \%$ \\
\hline 2 & 13a & $\mathrm{Ph}$ & $(R)-\mathbf{1 c}$ & Et & $14 a$ & $60 \%{ }^{7 b}$ \\
\hline 3 & 13a & $\mathrm{Ph}$ & $(S)-\mathbf{2 a}$ & $\mathrm{CH}_{2}\left(4-\mathrm{BnO}-\mathrm{C}_{6} \mathrm{H}_{4}\right)$ & 14a & $78 \%$ \\
\hline 4 & 13a & $\mathrm{Ph}$ & $(R)-1 \mathrm{c}$ & $\mathrm{CH}_{2}\left(4-\mathrm{BnO}-\mathrm{C}_{6} \mathrm{H}_{4}\right)$ & 14a & $87 \%{ }^{7 b}$ \\
\hline 5 & 13a & $\mathrm{Ph}$ & $(S)-\mathbf{2 a}$ & $t$-Bu & 14a & $82 \%$ \\
\hline 6 & 13a & $\mathrm{Ph}$ & $(R)-\mathbf{1 c}$ & $t$-Bu & $14 a^{b}$ & $70 \%{ }^{7 b}$ \\
\hline 7 & $13 b$ & 2-naphthyl & $(S)-\mathbf{2 a}$ & $t$-Bu & 14b & $90 \%$ \\
\hline 8 & 13c & $p$-biphenyl & $(S)-\mathbf{2 a}$ & $t$-Bu & $14 c$ & $87 \%$ \\
\hline 9 & 13d & $4-\mathrm{MeO}-\mathrm{C}_{6} \mathrm{H}_{4}$ & $(S)-\mathbf{2 a}$ & $t$-Bu & 14d & $77 \%$ \\
\hline 10 & $13 \mathrm{e}$ & $3,5-\left(\mathrm{CF}_{3}\right)_{2}-\mathrm{C}_{6} \mathrm{H}_{3}$ & $(S)-\mathbf{2 a}$ & $t$-Bu & $14 \mathrm{e}$ & $60 \%$ \\
\hline 11 & $13 f$ & 1-naphthyl & $(S)-\mathbf{2 a}$ & $t$-Bu & $14 f$ & $47 \%$ \\
\hline
\end{tabular}




\begin{tabular}{|c|c|c|c|c|c|c|}
\hline 12 & 13b & 2-naphthyl & $(S)-11^{\mathrm{c}}$ & $t-\mathrm{Bu}$ & $14 b$ & $69 \%$ \\
\hline 13 & $13 b$ & 2-naphthyl & $(S)-12^{\mathrm{c}}$ & $\mathrm{CH}_{2}\left(4-\mathrm{BnO}-\mathrm{C}_{6} \mathrm{H}_{4}\right)$ & $14 b$ & $60 \%$ \\
\hline
\end{tabular}

For the hydrogenation of 13a $(\mathrm{Ar}=\mathrm{Ph})$ in the presence of acid $(S)$-2a, three different Hantsch esters have been tested as the $\mathrm{H}$-transfer reagents $\left(\mathrm{R}=\mathrm{Et}, \mathrm{CH}_{2}\left(4-\mathrm{BnO}-\mathrm{C}_{6} \mathrm{H}_{3}\right), t\right.$-Bu; entries $1,3,5$ in Table 1). In all these experiments, the starting material has been converted quantitatively into the expected tetrahydroquinoline 14a after $2 \mathrm{~h}$ at room temperature. Enantiomeric excess of $77-78 \%$ were obtained by using the ethyl or the 4-benzyloxybenzyl esters, while the $t$-butyl ester afforded the desired product in slightly improved, 82\% ee. For comparison purposes, entries 2,4,6 in Table 1 recall the results obtained previously in the same reactions by using the ferrocene-derivative $1 \mathbf{c}$ as the acid catalyst.

The $t$-Bu Hantsch ester and catalyst $(S)$-2a were used then in the reduction of a larger set of substrates. Good enantiomeric excesses were obtained for $\mathrm{Ar}=2$-naphthyl, $p$-biphenyl and 4-MeO-phenyl, with ee between 77\% and 90\% (entries 7-9). The mixed amides (S)-11 and $(S)-\mathbf{1 2}$ have been tested also in the reduction of the $\alpha$-2-naphthylquinoline 13b (entries 12, 13). In spite of their lower pKa values, these catalysts gave lower catalytic activity and lower enantiomeric excesses than the corresponding phosphoric acids in entry 7.

\section{Conclusions}

This work complements our previous studies by highlighting the biphenylene-based paracyclophanes 2 as a new kind of planar chiral phosphoric acids giving promising levels of enantioselectivity in organocatalytic $\mathrm{H}$-transfer hydrogenations. With respect to the analogous ferrocene framework of $\mathbf{1}$, the biphenylene unit rigidifies the cyclophane conformation and gives advantages in terms of both synthetic availability and thermal stability of the corresponding phosphoric acids. This work corroborates the good potential of these paracyclophane scaffolds in enantioselective acid catalysis. Further studies on their catalytic applications are currently in progress.

\section{Experimental Section}

Anhydrous solvents were obtained by filtration through drying columns (THF, toluene, $\mathrm{CH}_{2} \mathrm{Cl}_{2}$ ). All reagents and solvents were of commercial quality and were used without further purification. Analytical thin-layer chromatography (TLC) was performed on plates precoated with silica gel layers. Flash column chromatography was performed using 40-63 mesh silica. NMR spectra $\left({ }^{1} \mathrm{H},{ }^{13} \mathrm{C}\right)$ were recorded at 500 or $300 \mathrm{MHz}$ spectrometers. High resolution mass spectrometry (HRMS) was performed using electrospray ionization (ESI) and time-of-flight (TOF) analyzer, in positive-ion or negative-ion detection mode.

1,8-Bis(4-(methoxymethoxy)phenyl)biphenylene (5). 1,8-Dibromobiphenylene 3 (22.55 g, 72.7 mmol), [4-(methoxymethoxy)phenyl]boronic acid $4(29.12 \mathrm{~g}, 160.0 \mathrm{mmol})$ and tri-o-furyl phosphine $(2.53 \mathrm{~g}$, $10.9 \mathrm{mmol}, 15 \mathrm{~mol} \%)$ were dissolved in 1,4-dioxane $(700 \mathrm{~mL})$ then a $1 \mathrm{M}$ solution of $\mathrm{Cs}_{2} \mathrm{CO}_{3}(290$ $\mathrm{mL})$ was added. The flask was evacuated and refilled with argon and $\mathrm{Pd}_{2} \mathrm{dba}_{3}(1.67 \mathrm{~g}, 1.82 \mathrm{mmol}, 2.5$ mol\%) was added under a flow of argon. The mixture was refluxed for $2 \mathrm{~h}$, then allowed to cool to room temperature, quenched with a saturated solution of $\mathrm{NH}_{4} \mathrm{Cl}$. The organic phase was extracted twice with EtOAc and dried over $\mathrm{MgSO}_{4}$ and the solvents were removed under reduced pressure. The black residue was purified by column chromatography (heptane/EtOAc $=95: 5$ to 9:1). The product 5 $\left(\mathrm{R}_{\mathrm{f}}=0,15\right.$ in heptane/EtOAc 7:3) was obtained as a pale yellow solid (17.0 g, 55\%). ${ }^{1} \mathrm{H}$ NMR (300 $\left.\mathrm{MHz}, \mathrm{CDCl}_{3}\right): \delta 6.86-6.81(\mathrm{~m}, 8 \mathrm{H}), 6.67-6.64(\mathrm{~m}, 2 \mathrm{H}), 6.60(\mathrm{~d}, J=8.3 \mathrm{~Hz}, 4 \mathrm{H}), 5.11(\mathrm{~s}, 4 \mathrm{H}), 3.48(\mathrm{~s}$, 6H); ${ }^{13} \mathrm{C}$ NMR (75 MHz, CDCl $): \delta 156.8$ (C), 151.4 (C ), 148.1 (C), 132.5 (C), 131.9 (C), 129.3 $(\mathrm{CH}), 128.8(\mathrm{CH}), 128.7(\mathrm{CH}), 115.5(\mathrm{CH}), 115.4(\mathrm{CH}), 94.7\left(\mathrm{CH}_{2}\right), 56.1\left(\mathrm{CH}_{3}\right)$ ppm. HRMS (ESI) calcd. for $\mathrm{C}_{28} \mathrm{H}_{24} \mathrm{NaO}_{4}[\mathrm{M}+\mathrm{Na}]^{+}$: 447.1572, found : 447.1563 . 


\section{1,8-Bis-[(4-(methoxymethoxy)-3-(4,4,5,5-tetramethyl-1,3,2-dioxaborolan-2yl)phenyl)]-biphenylene}

(6). In a flame dried round-bottomed flask is dissolved 1,1'-bis-[4-(methoxymethoxy)phenyl]biphenylene $5(8.4 \mathrm{~g}, 19.8 \mathrm{mmol})$ in anhydrous THF $(200 \mathrm{~mL})$. After cooling to $-78{ }^{\circ} \mathrm{C}, n$-BuLi $(2.5 \mathrm{M}$ solution in hexane, $47.5 \mathrm{~mL}, 118 \mathrm{mmol}, 6.0$ eq.) was added dropwise to the solution. After 5 minutes at $-78^{\circ} \mathrm{C}$ the mixture is allowed to warm to room temperature for $4 \mathrm{~h}$ (after few minutes at r.t. the pale yellow solution turns into a dark brown solution and after ca $20 \mathrm{~min}$ the dilithiated species appears as a white precipitate). Then the suspension is cooled to $-78{ }^{\circ} \mathrm{C}$ and 2-isopropoxy-4,4,5,5-tetramethyl1,3,2-dioxaborolane $(32.0 \mathrm{ml}, 158.3 \mathrm{mmol})$ is added dropwise and the suspension is stirred overnight at room temperature. To the resulting suspension was added a saturated aqueous solution of $\mathrm{NH}_{4} \mathrm{Cl}$ and EtOAc. The phases were separated and the aqueous phase is extracted once with EtOAc. The organic phases are dried over $\mathrm{MgSO}_{4}$ and the solvents were removed under reduced pressure. The procedure was repeated twice. The mixture was separated by flash chromatography on silica gel (eluent: Toluene/EtOAc $=9: 1)$ to afford $6\left(R_{f}=0.42\right.$ in heptane/EtOAc 7:3) as a pale yellow solid (19.0 g, 71\% for two batches). mp $176{ }^{\circ} \mathrm{C} ;{ }^{1} \mathrm{H}$ NMR $\left(300 \mathrm{MHz}, \mathrm{CDCl}_{3}\right): \delta 7.46(\mathrm{~d}, J=2.4 \mathrm{~Hz}, 2 \mathrm{H})$, 6.84-6.81 (m, 4H), $6.75(\mathrm{dd}, J=8.5,2.4 \mathrm{~Hz}, 2 \mathrm{H}), 6.63(\mathrm{~m}, 2 \mathrm{H}), 6.42(\mathrm{~d}, J=8.5 \mathrm{~Hz}, 2 \mathrm{H}), 5.12(\mathrm{~s}, 4 \mathrm{H})$, $3.51(\mathrm{~s}, 6 \mathrm{H}), 1.30(\mathrm{~s}, 24 \mathrm{H}) ;{ }^{13} \mathrm{C}$ NMR $\left(75 \mathrm{MHz}, \mathrm{CDCl}_{3}\right): \delta 161.4(\mathrm{C}), 151.3(\mathrm{C}), 148.1(\mathrm{C})$, 135.5(CH), $132.4(\mathrm{C}), 132.1(\mathrm{CH}), 131.3(\mathrm{C}), 129.4(\mathrm{CH}), 128.4(\mathrm{CH}), 115.2(\mathrm{CH}), 114.2(\mathrm{CH}), 95.3$ $\left(\mathrm{CH}_{2}\right), 83.3(\mathrm{C}), 56.1\left(\mathrm{CH}_{3}\right), 25.0\left(\mathrm{CH}_{3}\right), 24.9\left(\mathrm{CH}_{3}\right), 24.6\left(\mathrm{CH}_{3}\right)$ ppm; HRMS (ESI) calcd.for $\mathrm{C}_{40} \mathrm{H}_{46} \mathrm{O}_{8} \mathrm{~B}_{2} \mathrm{Na}[\mathrm{M}+\mathrm{Na}]^{+}$: 699.3276, found : 699.3293 .

1,8-Bis-[4-(hydroxy)-3-[(3',5'-diphenyl)phenyl]phenyl]biphenylene (8). Bis-boronate 6 (17.1 g, 25.2 $\mathrm{mmol})$, 1-bromo-3,5-diphenylbenzene $7(16.0 \mathrm{~g}, 51.7 \mathrm{mmol})$ and $\mathrm{Ba}(\mathrm{OH})_{2} .8 \mathrm{H}_{2} \mathrm{O}(31.8 \mathrm{~g}, 101 \mathrm{mmol})$, DME $(200 \mathrm{~mL})$ and water $(55 \mathrm{~mL})$ were introduced in a round bottomed flask. The flask was evacuated and refilled with argon (3 cycles), $\mathrm{Pd}\left(\mathrm{PPh}_{3}\right)_{4}(1.46 \mathrm{~g}, 1.26 \mathrm{mmol}, 5 \mathrm{~mol} \%)$ was added under a flow of argon. The mixture was refluxed for $18 \mathrm{~h}$. The resulting white suspension was allowed to cool to room temperature, diluted with $\mathrm{CH}_{2} \mathrm{Cl}_{2}$ and washed with water. The organic phase was dried over $\mathrm{MgSO}_{4}$ and concentrated in vacuo. The residue was taken up in 1,4-dioxane $(500 \mathrm{~mL})$ and $\mathrm{MeOH}$ $(500 \mathrm{~mL})$. Then, $\mathrm{HCl} 37 \%$ was added dropwise until $\mathrm{pH}=1(15 \mathrm{~mL})$ and the mixture was heated at 60 ${ }^{\circ} \mathrm{C}$ for $4 \mathrm{~h}$. A saturated aqueous solution of $\mathrm{NaHCO}_{3}$ was added, the layers were separated and the aqueous layer was extracted with EtOAc. After drying over $\mathrm{MgSO}_{4}$ the solvents were removed under reduced pressure. The mixture was separated by flash chromatography on silica gel (Toluene/EtOAc $=$ 97:3) to afford the desired product $\mathbf{8}\left(\mathrm{R}_{\mathrm{f}}=0,35\right.$ in heptane/EtOAc 8:2) as a pale yellow solid $(13.7 \mathrm{~g}$, 69\%). mp $224{ }^{\circ} \mathrm{C} ;{ }^{1} \mathrm{H}$ NMR (500 MHz, $\left.\mathrm{CDCl}_{3}\right): \delta 7.59$ (bs, $\left.2 \mathrm{H}\right), 7.46-7.45(\mathrm{~m}, 8 \mathrm{H}), 7.36-7.32(\mathrm{~m}$, $16 \mathrm{H}), 6.98(\mathrm{bs}, 2 \mathrm{H}), 6.93(\mathrm{~d}, J=8.1 \mathrm{~Hz}, 2 \mathrm{H}), 6.87-6.82(\mathrm{~m}, 4 \mathrm{H}), 6.68(\mathrm{~d}, J=6.5 \mathrm{~Hz}, 2 \mathrm{H}), 6.60(\mathrm{~d}, J=$ $8.0 \mathrm{~Hz}, 2 \mathrm{H}), 5.09(\mathrm{bs}, 2 \mathrm{H}) ;{ }^{13} \mathrm{C} \mathrm{NMR}\left(75 \mathrm{MHz}, \mathrm{CDCl}_{3}\right): \delta 152.2(\mathrm{C}), 151.4(\mathrm{C}), 147.8(\mathrm{C}), 142.4(\mathrm{C})$, $140.5(\mathrm{C}), 137.8(\mathrm{C}), 132.3(\mathrm{C}), 131.1(\mathrm{C}), 130.0(\mathrm{CH}), 129.6(\mathrm{CH}), 128.9(\mathrm{CH}), 128.8(\mathrm{CH}), 128.6$ $(\mathrm{CH}), 127.7(\mathrm{CH}), 127.3(\mathrm{CH}), 126.6(\mathrm{CH}), 125.2(\mathrm{CH}), 115.5(\mathrm{CH})$ ppm; HRMS (ESI) calcd. for $\mathrm{C}_{60} \mathrm{H}_{41} \mathrm{O}_{2}[\mathrm{M}+\mathrm{H}]^{+}:$793.3107, found: 793.3104 .

Synthesis of the epimeric phosphates 10. To a solution of bis-phenol $8(6.5 \mathrm{~g}, 8.2 \mathrm{mmol})$ and solid $1 \mathrm{H}$ tetrazole $(2.41 \mathrm{~g}, 34.4 \mathrm{mmol})$ in anhydrous DCM $(410 \mathrm{~mL})$ was added dropwise via cannula a solution of $(S)-2$ cyanoethyl-1-phenyl- $N, N, N^{\prime}, N^{\prime}$-tetra-isopropylphosphorodiamidite $(S)$-9 $(3.71 \mathrm{~g}, 9.8 \mathrm{mmol})$ in anhydrous DCM $(10 \mathrm{~mL})$. The mixture was heated at $40{ }^{\circ} \mathrm{C}$ for $3 \mathrm{~h}$, then quenched by addition of saturated aqueous $\mathrm{NaHCO}_{3}$ and extracted with DCM. The organic phase was dried over $\mathrm{MgSO}_{4}$ and the solvents were removed under reduced pressure. The crude macrocyclic phosphites were obtained as a 7:3 mixture of diastereoisomers and engaged in the next step without purification. ${ }^{31} \mathrm{P}$ NMR $\left(200 \mathrm{~Hz}, \mathrm{CDCl}_{3}\right): \delta 130.0$ (minor), $129.4 \mathrm{ppm}$ (major). HRMS (ESI) calcd. for $\mathrm{C}_{69} \mathrm{H}_{46} \mathrm{NO}_{3} \mathrm{NaP}[\mathrm{M}+\mathrm{Na}]^{+}: 990.3113$, found : 990.3148 .

The mixture of crude phosphites $(8.2 \mathrm{mmol}, 1$ eq.) was dissolved in DCM $(20 \mathrm{~mL})$. TBHP (5.5M in decane, $4.5 \mathrm{~mL}, 3$ eq.) was added to the solution at $0{ }^{\circ} \mathrm{C}$. After $15 \mathrm{~min}$, the reaction mixture was allowed to warm to room temperature and stirred for 45 minutes. The reaction was treated with saturated aqueous $\mathrm{Na}_{2} \mathrm{~S}_{2} \mathrm{O}_{3}$, the layers were separated, dried over $\mathrm{MgSO}_{4}$ and concentrated in vacuo. 
The crude phosphates were purified by chromatography on silica gel (eluent: toluene/EtOAc $=7: 3$ ) to afford the mixture of phosphates 10a and 10b (6.9 g, 86\% over 2 steps) as a pale yellow solid. Phosphates $\left(S, S_{P}\right)$-10a and $\left(S, R_{P}\right)$-10b were separated by semi-preparative HPLC on a $\mathrm{SiO}_{2}$ column ( $250 \times 10 \mathrm{~mm}, 5 \mathrm{mic}$ ) with toluene/heptane:THF (95:4:1) as the eluent; flow rate, $100 \mathrm{~mL} / \mathrm{min}$. Retention times: $10.0 \mathrm{~min}$ for $\left(S, S_{P}\right)-\mathbf{1 0 a}, 13.0 \mathrm{~min}$ for $\left(S, R_{P}\right) \mathbf{- 1 0 b}$.

$\left(S, S_{P}\right)$-10a (major diastereoisomer), white solid $\left(3.6 \mathrm{~g}, 45 \%\right.$ yield). mp $251{ }^{\circ} \mathrm{C} .{ }^{31} \mathrm{P}$ NMR $(200 \mathrm{MHz}$, $\left.\mathrm{CDCl}_{3}\right): \delta-17.2 \mathrm{ppm} ;{ }^{1} \mathrm{H}$ NMR $\left(300 \mathrm{MHz}, \mathrm{CDCl}_{3}\right): \delta 7.91$ (bs, $\left.1 \mathrm{H}\right), 7.78$ (bs, 3H), $7.70(\mathrm{~d}, J=7.4$ $\mathrm{Hz}, 4 \mathrm{H}), 7.65-7.62(\mathrm{~m}, 6 \mathrm{H}), 7.45-7.34(\mathrm{~m}, 12 \mathrm{H}), 7.29(\mathrm{~d}, J=7.5 \mathrm{~Hz}, 2 \mathrm{H}), 7.14(\mathrm{t}, J=7.5 \mathrm{~Hz}, 1 \mathrm{H})$, $7.03(\mathrm{t}, J=7.6 \mathrm{~Hz}, 2 \mathrm{H}), 6.94-6.86(\mathrm{~m}, 3 \mathrm{H}), 6.81-6.74(\mathrm{~m}, 4 \mathrm{H}), 6.68-6.63(\mathrm{~m}, 2 \mathrm{H}), 6.21(\mathrm{dd}, J=8.5,2.2$ $\mathrm{Hz}, 1 \mathrm{H}), 6.14(\mathrm{~d}, J=8.5 \mathrm{~Hz}, 1 \mathrm{H}), 6.08(\mathrm{dd}, J=8.5,2.2 \mathrm{~Hz}, 1 \mathrm{H}), 5.17\left(\mathrm{ddd}, J_{\mathrm{H}-\mathrm{P}}=7.7, J=6.5,5.5 \mathrm{~Hz}\right.$, $1 \mathrm{H}), 2.44(\mathrm{dd}, J=16.5,6.5 \mathrm{~Hz}, 1 \mathrm{H}), 2.34(\mathrm{dd}, J=16.5,5.5 \mathrm{~Hz}, 1 \mathrm{H}) ;{ }^{13} \mathrm{C} \mathrm{NMR}\left(75 \mathrm{MHz}, \mathrm{CDCl}_{3}\right): \delta$ 151.6. (C), 151.5 (C), 149.6 (C), 149.2 (C), 149.1 (d, $\left.J_{\mathrm{C}-\mathrm{P}}=5.9 \mathrm{~Hz}, \mathrm{C}-\mathrm{O}\right), 146.8$ (d, $J_{\mathrm{C}-\mathrm{P}}=8.3 \mathrm{~Hz}, \mathrm{C}-$ O), $142.5(\mathrm{C}), 142.0(\mathrm{C}), 141.0$ (C), 140.5 (C), 138.1 (C), 137.9 (C), 136.9 (C), 136.5 (C), 136.1 (d, $J_{\mathrm{C}-}$ $\left.\mathrm{P}=3.9 \mathrm{~Hz}, \mathrm{C}_{\mathrm{Ph}}\right), 132.9(\mathrm{C}), 131.8(\mathrm{C}), 131.5(\mathrm{C}), 131.1(\mathrm{C}), 131.0(\mathrm{C}), 129.5(\mathrm{CH}), 129.2(\mathrm{CH}), 129.0$ $(\mathrm{CH}), 128.9(\mathrm{CH}), 128.2(\mathrm{CH}), 128.1(\mathrm{CH}), 128.0(\mathrm{CH}), 127.7(\mathrm{CH}), 127.6(\mathrm{CH}), 127.5(\mathrm{CH}), 127.4$ $(\mathrm{CH}), 127.2(\mathrm{CH}), 127.0(\mathrm{CH}), 125.9(\mathrm{CH}), 125.8(\mathrm{CH}), 125.6(\mathrm{CH}), 121.9(\mathrm{CH}), 118.9(\mathrm{CH}), 116.8$ $(\mathrm{CH}), 114.9(\mathrm{CN}), 76.7(\mathrm{OCH}), 26.9\left(\mathrm{~d}, J_{\mathrm{C}-\mathrm{P}}=7.7 \mathrm{~Hz}, \mathrm{CH}_{2}\right) \mathrm{ppm}$; HRMS (ESI) calcd. for $\mathrm{C}_{69} \mathrm{H}_{47} \mathrm{NO}_{4} \mathrm{P}$ $[\mathrm{M}+\mathrm{H}]^{+}: 984.3243$, found : 984.3210. $[\alpha]_{\mathrm{D}}^{20}:+68\left(c=1.0, \mathrm{CHCl}_{3}\right)$.

$\left(S, R_{P}\right)$-10b (minor diastereoisomer), white solid $\left(1.8 \mathrm{~g}, 22 \%\right.$ yield). mp $253{ }^{\circ} \mathrm{C} .{ }^{31} \mathrm{P}$ NMR $(200 \mathrm{MHz}$, $\left.\mathrm{CDCl}_{3}\right): \delta-17.7 \mathrm{ppm} .{ }^{1} \mathrm{H}$ NMR $\left(300 \mathrm{MHz}, \mathrm{CDCl}_{3}\right): 7.90(\mathrm{bs}, 1 \mathrm{H}), 7.81(\mathrm{~d}, J=1.4 \mathrm{~Hz}, 2 \mathrm{H}), 7.77$ (bs, $1 \mathrm{H}), 7.71(\mathrm{~d}, J=7.6 \mathrm{~Hz}, 4 \mathrm{H}), 7.65(\mathrm{~d}, J=7.6 \mathrm{~Hz}, 6 \mathrm{H}), 7.48-7.30(\mathrm{~m}, 14 \mathrm{H}), 7.16-7.10(\mathrm{~m}, 1 \mathrm{H}), 7.02-$ $6.96(\mathrm{~m}, 4 \mathrm{H}), 6.81-6.77(\mathrm{~m}, 4 \mathrm{H}), 6.68-6.64(\mathrm{~m}, 2 \mathrm{H}), 6.60(\mathrm{~d}, J=8.4 \mathrm{~Hz}, 1 \mathrm{H}), 6.15-6.10(\mathrm{~m}, 2 \mathrm{H}), 6.02$ $(\mathrm{dd}, J=8.4,2.1 \mathrm{~Hz}, 1 \mathrm{H}), 5.40\left(\mathrm{ddd}, J_{\mathrm{H}-\mathrm{P}}=8.2, J=8.2,4.6 \mathrm{~Hz}, 1 \mathrm{H}\right), 2.57(\mathrm{dd}, J=16.6,4.6 \mathrm{~Hz}, 1 \mathrm{H})$, $2.37(\mathrm{dd}, J=16.6,8.2 \mathrm{~Hz}, 1 \mathrm{H}) .{ }^{13} \mathrm{C}$ NMR $\left(75 \mathrm{MHz}, \mathrm{CDCl}_{3}\right): \delta 151.5(\mathrm{C}), 149.4(\mathrm{C}), 148.2\left(\mathrm{~d}, J_{\mathrm{C}-\mathrm{P}}=\right.$ $8.3 \mathrm{~Hz}, \mathrm{C}-\mathrm{O}$ ), 147.8 (d, J $\left.J_{\mathrm{C}-\mathrm{P}}=8.9 \mathrm{~Hz}, \mathrm{C}-\mathrm{O}\right), 142.6$ (C), 142.2 (C), 141.1 (C ), 140.5 (C), 138.0 (C), $137.6(\mathrm{C}), 136.9(\mathrm{C}), 136.7(\mathrm{C}), 135.6\left(\mathrm{~d}, J_{\mathrm{C}-\mathrm{P}}=6.0 \mathrm{~Hz}, \mathrm{C}_{\mathrm{Ph}}\right), 132.2(\mathrm{C}), 132.1(\mathrm{C}), 131.6(\mathrm{C}), 131.1$ (C), $131.0(\mathrm{C}), 129.7(\mathrm{CH}), 129.2(\mathrm{CH}), 129.0(\mathrm{CH}), 128.9(\mathrm{CH}), 128.4(\mathrm{CH}), 128.2(\mathrm{CH}), 128.0$ $(\mathrm{CH}), 127.6(\mathrm{CH}), 127.4(\mathrm{CH}), 127.1(\mathrm{CH}), 126.3(\mathrm{CH}), 126.0(\mathrm{CH}), 125.7(\mathrm{CH}), 120.7(\mathrm{CH}), 120.0$ $(\mathrm{CH}), 116.8(\mathrm{CH}), 115.0(\mathrm{CN}), 76.1\left(\mathrm{~d}, J_{\mathrm{C}-\mathrm{P}}=5.6 \mathrm{~Hz}, \mathrm{OCH}\right), 26.0\left(\mathrm{~d}, J_{\mathrm{C}-\mathrm{P}}=4.3 \mathrm{~Hz}, \mathrm{CH}_{2}\right) \mathrm{ppm}$. HRMS (ESI) calcd. for $\mathrm{C}_{69} \mathrm{H}_{47} \mathrm{NO}_{4} \mathrm{P}: 984.3243$, found: 984.3212. $[\alpha]_{\mathrm{D}}^{20}:-123\left(c=1.0, \mathrm{CHCl}_{3}\right)$.

Phosphoric acid (S)-2a. DBU (920 $\mu \mathrm{L}, 6.1 \mathrm{mmol})$ was added dropwise to a solution of phosphate $\left(S, S_{P}\right)-10 \mathbf{a}$ $(3.0 \mathrm{~g}, 3.0 \mathrm{mmol})$ in DCM $(15 \mathrm{~mL})$. After $30 \mathrm{~min}$ at room temperature, the crude DBU phosphate salt was purified by column chromatography (eluent: $\mathrm{MeOH} / \mathrm{DCM}=0: 100$ to $5: 95$ ) to remove the side-product cinnamonitrile. The fractions were collected, concentrated in vacuo and diluted in DCM $(15 \mathrm{~mL})$. The solution was treated with $\mathrm{HCl} 6 \mathrm{~N}\left(3^{*} 15 \mathrm{~mL}\right)$. The layers were separated and the organic layer was concentrated in vacuo to afford the chiral phosphoric acid (S)-2a (2.40 g, 92\% yield) as a white solid. mp $306{ }^{\circ} \mathrm{C} ;{ }^{31} \mathrm{P}(125 \mathrm{MHz}$, $\left.\mathrm{CDCl}_{3}\right): \delta-11.4 ;{ }^{1} \mathrm{H}$ NMR $\left(500 \mathrm{MHz}, \mathrm{CDCl}_{3}\right): \delta 7.66$ (bs, 2H), 7.65 (bs, 4H), $7.61(\mathrm{~d}, J=7.7 \mathrm{~Hz}$, $8 \mathrm{H}), 7.44(\mathrm{~d}, J=1.7 \mathrm{~Hz}, 2 \mathrm{H}), 7.34(\mathrm{t}, J=7.7 \mathrm{~Hz}, 8 \mathrm{H}), 7.24(\mathrm{t}, J=7.7 \mathrm{~Hz}, 4 \mathrm{H}), 6.93-6.89(\mathrm{~m}, 4 \mathrm{H})$, $6.77(\mathrm{dd}, J=5.1,2.4 \mathrm{~Hz}, 2 \mathrm{H}), 6.39(\mathrm{~d}, J=8.5 \mathrm{~Hz}, 2 \mathrm{H}), 6.02(1 \mathrm{H}), 6.00(\mathrm{dd}, J=8.5,1.7 \mathrm{~Hz}, 2 \mathrm{H}) ;{ }^{13} \mathrm{C}$ NMR (125 MHz, $\mathrm{CDCl}_{3}$ ): $\delta 151.9(\mathrm{C}), 149.7(\mathrm{C}), 148.2\left(\mathrm{~d}, J_{\mathrm{C}-\mathrm{P}}=7.6 \mathrm{~Hz}, \mathrm{C}-\mathrm{O}\right), 142.5(\mathrm{C}), 141.3(\mathrm{C})$, $137.8(\mathrm{C}), 136.5(\mathrm{C}), 132.0(\mathrm{C}), 131.9\left(\mathrm{~d}, J_{\mathrm{C}-\mathrm{P}}=5.9 \mathrm{~Hz}, \mathrm{C}_{\mathrm{Ph}}\right), 129.0(\mathrm{CH}), 128.2(\mathrm{CH}), 128.1(\mathrm{CH})$, $127.9(\mathrm{CH}), 127.6(\mathrm{CH}), 127.1(\mathrm{CH}), 126.0(\mathrm{CH}), 120.8(\mathrm{CH}), 116.8(\mathrm{CH})$ ppm; HRMS (ESI) calcd. for $\mathrm{C}_{60} \mathrm{H}_{38} \mathrm{O}_{4} \mathrm{P}: 853.2513$, found: 853.2493; $[\alpha]_{\mathrm{D}}^{20}:+90\left(c=0.5, \mathrm{CHCl}_{3}\right)$.

Representative procedure for the synthesis of the mixed imides 11 and 12. (a) Conversion of (S)$2 \boldsymbol{a}$ into the corresponding chlorophosphate. A solution of triphenylphosphine (105 $\mathrm{mg}, 0.40 \mathrm{mmol})$ in anhydrous dichloromethane $(1.5 \mathrm{~mL})$ was added dropwise to a solution of phosphoric acid $(S)-\mathbf{2 a}(171$ $\mathrm{mg}, 0.20 \mathrm{mmol})$ and 2,2,2-trichloroacetonitrile $(40 \mu \mathrm{L}, 0.40 \mathrm{mmol})$ in anhydrous dichloromethane (1.5 
$\mathrm{mL}$ ). The mixture was stirred for $1 \mathrm{~h}$ at r.t., then the solvent was evaporated under reduced pressure and the residue was purified on silica gel (heptane/ethyl acetate $=9: 1$ to $8: 2$ ) to afford the desired chlorophosphate as a white solid (150 mg, $86 \%$ ). $\mathrm{R}_{\mathrm{f}}=0,5$ (heptanes/ethyl acetate 8:2); $\mathrm{mp} 282{ }^{\circ} \mathrm{C}$; ${ }^{31} \mathrm{P} \mathrm{NMR}\left(200 \mathrm{MHz}, \mathrm{CDCl}_{3}\right): \delta-14.0 \mathrm{ppm} ;{ }^{1} \mathrm{H}$ NMR $\left(500.1 \mathrm{MHz}, \mathrm{CDCl}_{3}\right): \delta 7.87(\mathrm{t}, J=1.6 \mathrm{~Hz}, 1 \mathrm{H}), 7.85(\mathrm{t}, J$ $=1.6 \mathrm{~Hz}, 1 \mathrm{H}), 7.81(\mathrm{~d}, J=1.6 \mathrm{~Hz}, 2 \mathrm{H}), 7.79(\mathrm{~d}, J=1.6 \mathrm{~Hz}, 2 \mathrm{H}), 7.75(\mathrm{~d}, J=8.0 \mathrm{~Hz}, 4 \mathrm{H}), 7.73(\mathrm{~d}, J=8.0 \mathrm{~Hz}$, 4H), $7.54(\mathrm{bs}, 2 \mathrm{H}), 7.52-7.48(\mathrm{~m}, 8 \mathrm{H}), 7.41(\mathrm{t}, J=8.0 \mathrm{~Hz}, 2 \mathrm{H}), 7.39(\mathrm{t}, J=8.0 \mathrm{~Hz}, 2 \mathrm{H}), 6.92-6.86(\mathrm{~m}, 4 \mathrm{H}), 6.77$ $(\mathrm{d}, J=7.0 \mathrm{~Hz}, 2 \mathrm{H}), 6.63(\mathrm{~d}, J=8.5 \mathrm{~Hz}, 1 \mathrm{H}), 6.61(\mathrm{~d}, J=8.5 \mathrm{~Hz}, 1 \mathrm{H}), 6.29(\mathrm{dd}, J=8.5,2.1 \mathrm{~Hz}, 1 \mathrm{H}), 6.26(\mathrm{dd}, J$ $=8.5,2.1 \mathrm{~Hz}, 1 \mathrm{H}) \cdot{ }^{13} \mathrm{C} \mathrm{NMR}\left(75.5 \mathrm{MHz}, \mathrm{CDCl}_{3}\right): \delta 151.6(\mathrm{C}), 149.5(\mathrm{C}), 149.4(\mathrm{C}), 148.6\left(\mathrm{~d}, J_{\mathrm{C}-\mathrm{P}}=12.2\right.$ Hz, C-O), 148.2 (d, $\left.J_{\mathrm{C}-\mathrm{P}}=12.2 \mathrm{~Hz}, \mathrm{C}-\mathrm{O}\right), 142.7$ (C), 142.6 (C), 141.1 (C), 140.9 (C), 137.6 (C), 137.5 (C), $137.0(\mathrm{C}), 132.2\left(\mathrm{~d}, J_{\mathrm{C}-\mathrm{P}}=6.4 \mathrm{~Hz}, \mathrm{C}_{\mathrm{Ph}}\right), 131.5(\mathrm{C}), 131.4(\mathrm{C}), 129.1(\mathrm{CH}), 129.0(\mathrm{CH}), 128.8$ $(\mathrm{CH}), 128.5(\mathrm{CH}), 128.3(\mathrm{CH}), 128.1(\mathrm{CH}), 127.9(\mathrm{CH}), 127.7(\mathrm{CH}), 127.5(\mathrm{CH}), 127.3(\mathrm{CH}), 127.2$ $(\mathrm{CH}), 126.5(\mathrm{CH}), 126.3(\mathrm{CH}), 121.2(\mathrm{CH}), 119.2(\mathrm{CH}), 117.0(\mathrm{CH})$ ppm; HRMS (ESI) calcd.for $\mathrm{C}_{60} \mathrm{H}_{39} \mathrm{O}_{3} \mathrm{ClP}[\mathrm{M}+\mathrm{H}]^{+}:$873.2325, found : 873.2340. $[\alpha]_{\mathrm{D}}^{20}:+89\left(c=1, \mathrm{CHCl}_{3}\right)$.

(b) Synthesis of the mixed imide 11. To a solution of potassium carbonate $(33 \mathrm{mg}, 0.24 \mathrm{mmol})$ and trifluoromethanesulfonamide $(36 \mathrm{mg}, 0.24 \mathrm{mmol})$ in anhydrous acetonitrile $(2.5 \mathrm{~mL})$ at r.t. was added a solution of chlorophosphate $(105 \mathrm{mg}, 0.12 \mathrm{mmol})$ in anhydrous dichloromethane/acetonitrile $(0.5$ $\mathrm{mL} / 2.5 \mathrm{~mL}$ ). The mixture was heated at $60^{\circ} \mathrm{C}$ for $16 \mathrm{~h}$. The solvent was evaporated under reduced pressure and the residue was purified on silica gel (eluent: heptane/ethyl acetate gradient, from 8:2 to 5:5). The fractions were collected, concentrated in vacuo and diluted in DCM (5 mL). This solution was treated with $\mathrm{HCl} 6 \mathrm{~N}(3 * 5 \mathrm{~mL})$. The layers were separated and the organic layer was concentrated in vacuo to afford 11 as a white solid (105 $\mathrm{mg}, 89 \%$ yield). $\mathrm{Rf}=0,6$ (heptane/ethyl acetate 1:1); mp $235{ }^{\circ} \mathrm{C} ;{ }^{31} \mathrm{P}$ NMR $\left(202.5 \mathrm{~Hz}, \mathrm{CDCl}_{3}\right): \delta-18.8 \mathrm{ppm} ;{ }^{19} \mathrm{~F}$ NMR $\left(282.4 \mathrm{~Hz}, \mathrm{CDCl}_{3}\right): \delta-77.6 \mathrm{ppm} ;{ }^{1} \mathrm{H}$ NMR (300.2 MHz, $\left.\mathrm{CDCl}_{3}\right): \delta 7.91(\mathrm{bs}, 1 \mathrm{H}), 7.77$ (bs, 4H), $7.73(\mathrm{~d}, J=7.7 \mathrm{~Hz}, 4 \mathrm{H}), 7.65(\mathrm{bs}, 1 \mathrm{H})$, $7.62(\mathrm{~d}, J=7.7 \mathrm{~Hz}, 4 \mathrm{H}), 7.55(\mathrm{bs}, 1 \mathrm{H}), 7.52(\mathrm{bs}, 1 \mathrm{H}), 7.45-7.31(\mathrm{~m}, 12 \mathrm{H}), 7.04-6.83(\mathrm{~m}, 6 \mathrm{H}), 6.74(\mathrm{~d}$, $J=8.5 \mathrm{~Hz}, 1 \mathrm{H}), 6.51(\mathrm{~d}, J=8.5 \mathrm{~Hz}, 1 \mathrm{H}), 6.29(\mathrm{dd}, J=8.5,2.1 \mathrm{~Hz}, 1 \mathrm{H}), 6.25(\mathrm{dd}, J=8.5,2.1 \mathrm{~Hz}, 1 \mathrm{H})$; ${ }^{13} \mathrm{C}$ NMR (75.5 MHz, $\left.\mathrm{CDCl}_{3}\right): \delta 151.7(\mathrm{C}), 149.8(\mathrm{C}), 149.4(\mathrm{C}), 149.3\left(\mathrm{~d}, J_{\mathrm{C}-\mathrm{P}}=8.8 \mathrm{~Hz}, \mathrm{C}-\mathrm{O}\right), 144.6$ $\left(\mathrm{d}, J_{\mathrm{C}-\mathrm{P}}=8.8 \mathrm{~Hz}, \mathrm{C}-\mathrm{O}\right), 142.5(\mathrm{C}), 142.4(\mathrm{C}), 141.3(\mathrm{C}), 141.0(\mathrm{C}), 137.9$ (C), 137.5 (C), $137.1(\mathrm{C})$, $136.8(\mathrm{C}), 132.9(\mathrm{C}), 132.0(\mathrm{C}), 131.8\left(\mathrm{~d}, J_{\mathrm{C}-\mathrm{P}}=8.2 \mathrm{~Hz}, \mathrm{C}_{\mathrm{Ph}}\right), 131.6(\mathrm{C}), 129.2(\mathrm{CH}), 128.9(\mathrm{CH})$, $128.7(\mathrm{CH}), 128.4(\mathrm{CH}), 128.2(\mathrm{CH}), 128.1(\mathrm{CH}), 127.7(\mathrm{CH}), 127.5(\mathrm{CH}), 127.0(\mathrm{CH}), 126.3(\mathrm{CH})$, $125.9(\mathrm{CH}), 122.2(\mathrm{CH}), 119.1\left(\mathrm{q}, J_{\mathrm{C}-\mathrm{F}}=321.2 \mathrm{~Hz}, \mathrm{CF}_{3}\right), 118.5(\mathrm{CH}), 117.0(\mathrm{CH})$; HRMS (ESI) calcd.forC ${ }_{61} \mathrm{H}_{40} \mathrm{NO}_{5} \mathrm{~F}_{3} \mathrm{PS}[\mathrm{M}+\mathrm{H}]^{+}:$986.2317, found : 986.2324; $[\alpha]_{\mathrm{D}}^{20}:+99\left(\mathrm{c}=1, \mathrm{CHCl}_{3}\right)$.

Mixed imide 12: ${ }^{31} \mathrm{P}$ NMR $\left(202.5 \mathrm{MHz} \mathrm{CDCl}_{3}\right): \delta-10.5 \mathrm{ppm} ;{ }^{19} \mathrm{~F} \mathrm{NMR}\left(282.4 \mathrm{MHz}, \mathrm{CDCl}_{3}\right):-78.7$ ppm; ${ }^{1} \mathrm{H}$ NMR $\left(500.1 \mathrm{MHz}\right.$, DMSO- $\left.d_{6^{-}} 90{ }^{\circ} \mathrm{C}\right)$ : 7.91-7.87 (m, $\left.10 \mathrm{H}\right), 7.81-7.80(\mathrm{~m}, 2 \mathrm{H}), 7.71-7.64(\mathrm{~m}$, $2 \mathrm{H}), 7.53-7.48(\mathrm{~m}, 8 \mathrm{H}), 7.39(\mathrm{t}, J=7.1 \mathrm{~Hz}, 4 \mathrm{H}), 7.25-7.22(\mathrm{~m}, 3 \mathrm{H}), 6.52(\mathrm{~d}, J=8.2 \mathrm{~Hz}, 1 \mathrm{H}), 6.43(\mathrm{~d}$, $J=8.2 \mathrm{~Hz}, 1 \mathrm{H}), 6.36(\mathrm{~d}, J=8.2 \mathrm{~Hz}, 1 \mathrm{H}), 4.90(\mathrm{~s}, 1 \mathrm{H}), 4.87(\mathrm{~s}, 1 \mathrm{H}), 4.68(\mathrm{~s}, 1 \mathrm{H}), 4.62(\mathrm{~s}, 1 \mathrm{H}), 4.40(\mathrm{~s}$, $2 \mathrm{H}), 4.37(\mathrm{~s}, 2 \mathrm{H}) ;{ }^{13} \mathrm{C}$ NMR $\left(125.7 \mathrm{MHz}, \mathrm{DMSO}-d_{6^{-}} 90{ }^{\circ} \mathrm{C}\right): \delta 148.0\left(\mathrm{~d}, J_{\mathrm{C}-\mathrm{P}}=7.2 \mathrm{~Hz}, \mathrm{C}\right), 146.4\left(\mathrm{~d}, J_{\mathrm{C}-}\right.$ $\mathrm{P}=9.2 \mathrm{~Hz}, \mathrm{C}), 140.0(\mathrm{C}), 139.7(\mathrm{C}), 138.2(\mathrm{C}), 137.5(\mathrm{C}), 131.8(\mathrm{C}), 131.4(\mathrm{C}), 129.3$ (d, $J_{\mathrm{C}-\mathrm{P}}=9.0 \mathrm{~Hz}$, C), $128.6(\mathrm{C}), 127.6(\mathrm{CH}), 127.5(2 \mathrm{CH}), 127.4(\mathrm{CH}), 127.1(\mathrm{C}), 126.2(\mathrm{CH}), 126.1(\mathrm{CH}), 126.0(\mathrm{CH})$, $125.8(\mathrm{CH}), 125.7(\mathrm{CH}), 125.6(2 \mathrm{CH}), 124.7(\mathrm{CH}), 124.2(\mathrm{CH}), 123.1(\mathrm{CH}), 122.8(\mathrm{CH}), 122.5(\mathrm{CH})$, $118.7(\mathrm{CH}), 85.4(\mathrm{C}), 85.2(\mathrm{C}), 67.8(2 \mathrm{CH}), 67.1(2 \mathrm{CH}), 65.4(\mathrm{CH}), 65.0(\mathrm{CH}), 64.4(2 \mathrm{CH})$; HRMS (ESI) calcd.for $\mathrm{C}_{59} \mathrm{H}_{40} \mathrm{NF}_{3} \mathrm{FeO}_{5} \mathrm{PS}[\mathrm{M}-\mathrm{H}]: 1018.1666$, found :1018.1647; $[\alpha]_{\mathrm{D}}^{20}=+747\left(\mathrm{c}=1, \mathrm{CHCl}_{3}\right)$.

Representative procedure for the catalytic reductions of $\alpha$-arylquinolines. A solution of 2phenylquinoline 13a (11 mg, $0.05 \mathrm{mmol})$, Hantzsch dihydropyridine ( $\mathrm{R}=\mathrm{Et}, 0.12 \mathrm{mmol})$ and the acid catalyst $(S)$-2a $(0.005 \mathrm{mmol})$ in toluene $(1 \mathrm{ml})$ was stirred at r.t. for $2 \mathrm{~h}$. The solvent was removed under reduced pressure and the residue was purified on silica gel with toluene as the eluent. 2-Phenyl1,2,3,4-tetrahydroquinoline 14a was obtained as a colorless oil. The enantiomeric excess was determined by HPLC using a CHIRALPAK® IB column. Eluent: $i$-PrOH/n-heptane 5:95, at a flow 
rate of $1 \mathrm{~mL} / \mathrm{min}$ [detection at $275 \mathrm{~nm}$ ]. Retention times: $6.7 \mathrm{~min}$ for $(S)-\mathbf{1 4 a}$ and $8.2 \mathrm{~min}$ for $(R)-\mathbf{1 4 a}$. $\left[\operatorname{Litt:}^{18}(S)-\mathbf{1 4 a}:[\alpha]_{\mathrm{D}}=-35.7\left(\mathrm{c}=0.8, \mathrm{CHCl}_{3}\right)\right]$.

The same procedure was applied to the reduction of quinolines 13b-f. Spectral data for the corresponding tetrahydroquinolines $\mathbf{1 4 b - f}$ and conditions for ee measurements by HPLC have been reported previously. ${ }^{7 b}$

\section{Computational Method}

Calculations have been carried out with the Gaussian09 package of programs. ${ }^{19}$ All the structures were optimized at the DFT level by means of the M06 functional. ${ }^{20}$ The 6-31G(d,p) basis set was applied for all atoms. This level of calculation has been previously shown to provide reliable structures for phosphoric acids derivatives. ${ }^{7 \mathrm{~b}}$ To get accurate geometries and energies, the SCF convergence criterion has been systematically tightened to $10^{-8}$ a.u., and the force minimizations were carried out until the rms force becomes smaller than (at least) $1 \times 10^{-5}$ a.u. The optimized geometries were characterized by harmonic analysis, and the nature of the stationary points was determined according to the number of negative eigenvalues of the Hessian matrix

Acknowledgements. We are grateful to the Agence Nationale de la Recherche (ANR) for financial support to this work, within the ANR Blanc "Chiracid" project. We thank the COST action "ORganoCAtalysis" CM0905. This work was granted access to the HPC resources of CINES under allocation x2013086894 made by GENCI (Grand Equipment National de Calcul Intensif). The work of K.K. and I.L. was supported by the institutional research funding IUT14-20 (TLOKT14014I) from the Estonian Ministry of Education and Research.

Associated content. Copies of the ${ }^{1} \mathrm{H},{ }^{13} \mathrm{C}$ and ${ }^{31} \mathrm{P}$ NMR spectra, $\mathrm{X}$-ray crystal data for 10a, details for pKa measurements. This material is available free of charge via the Internet at http://pubs.acs.org.

\section{Author Information}

Corresponding authors: angela.marinetti@cnrs.fr jean-francois.betzer@cnrs.fr

\section{References}

(1) (a) Akiyama, T.; Itoh, J.; Fuchibe, K. Adv. Synth. Catal. 2006, 348, 999. (b) Akiyama, T. Chem. Rev. 2007, 107, 5744. (c) Terada, M. Synthesis 2010, 1929. (d) Terada, M. Bull. Chem. Soc. Jpn. 2010, 83, 101. (e) Yu, J.; Shi, F.; Gong, L.-Z. Acc. Chem. Res. 2011, 44, 1156.

(2) (a) Hamilton, G. L.; Kang, E. J.; Mba, M.; Toste, F. D. Science 2007, 317, 496. (b) Phipps, R. J.; Hamilton, G. L.; Toste, F. D. Nat. Chem. 2012, 4, 603. (c) Lv, J.; Luo, S. Chem. Commun. 2013, 49, 847. (d) Mahlau, M.; List, B. Angew. Chem. Int. Ed. 2013, 52, 518. (e) Brak, K.; Jacobsen, E. N. Angew. Chem. Int. Ed. 2013, 52, 534.

(3) Xie, J.-H.; Zhou, Q.-L. Acc. Chem. Res. 2008, 41, 581.

(4) (a) Akiyama, T.; Saitoh, Y.; Morita, H.; Fuchibe, K. Adv. Synth. Catal. 2005, 347, 1523. (b) Lam, H. W. Synthesis 2011, 2011. (c) Gratzer, K.; Gururaja, G. N.; Waser, M. Eur. J. Org. Chem. 2013, 4471. (d) Seebach, D.; Beck, A. K.; Bichsel, H.-U.; Pichota, A.; Sparr, C.; Wünsch, R.; Schweizer, W. B. Helv. Chim. Acta 2012, 95, 1303.

(5) (a) Čorić, I.; Müller, S.; List, B. J. Am. Chem. Soc. 2010, 132, 17370. (b) Xing, C.-H.; Liao, Y.-X.; Ng, J.; Hu, Q.-S. J. Org. Chem. 2011, 76, 4125. (c) Chen, Z.; Wang, B.; Wang, Z.; Zhu, G.; Sun, J. Angew. Chem. Int. Ed. 2013, 52, 2027. (d) Li, X.; Zhao, Y.; Qu, H.; Mao, Z.; Lin, X. Chem. Commun. 2013, 49, 1401. (e) Huang, D.; Li, X.; Xu, F.; 
Li, L.; Lin, X. ACS Catalysis 2013, 3, 2244. (f) Caruana, L.; Fochi, M.; Ranieri, S.; Mazzanti, A.; Bernardi, L. Chem. Commun. 2013, 49, 880. (g) Mori, K.; Ichikawa, Y.; Kobayashi, M.; Shibata, Y.; Yamanaka, M.; Akiyama, T. J. Am. Chem. Soc. 2013, 135, 3964. (h) Mensah, E.; Camasso, N.; Kaplan, W.; Nagorny, P. Angew. Chem. Int. Ed. 2013, 52, 12932. (i) Wang, Z.; Law, W. K.; Sun, J. Org. Lett. 2013, 15, 5964. (j) Xie, W.; Jiang, G.; Liu, H.; Hu, J.; Pan, X.; Zhang, H.; Wan, X.; Lai, Y.; Ma, D. Angew. Chem. Int. Ed. 2013, 52, 12924. (k) Romanov-Michailidis, F.; Guénée, L.; Alexakis, A. Org. Lett. 2013, 15, 5890. (1) He, L.; Laurent, G.; Retailleau, P.; Folléas, B.; Brayer, J.L.; Masson, G. Angew. Chem. Int. Ed. 2013, 52, 11088. (m) Kimura, T.; Sekine, M.; Takahashi, D.; Toshima, K. Angew. Chem. Int. Ed. 2013, 52, 12131. (n)Phipps, R. J.; Toste, F. D. J. Am. Chem. Soc. 2013, 135, 1268. (o) Kano, T.; Takechi, R.; Kobayashi, R.; Maruoka, K. Org. Biomol. Chem. 2014, 12, 724. (p) Tang, W.; Johnston, S.; Li, C.; Iggo, J. A.; Bacsa, J.; Xiao, J. Chem. Eur. J. 2013, 19, 14187. (q) Calleja, J.; GonzalezPerez, A. B.; De Lera, A. R.; Alvarez, R.; Fananas, F. J.; Rodriguez, F. Chem. Sci. 2014, 5, 996. (r) Dagousset, G.; Erb, W.; Zhu, J.; Masson, G. Org. Lett. 2014, 16, 2554. (s) Makiguchi, K.; Yamanaka, T.; Kakuchi, T.; Terada, M.; Satoh, T. Chem. Commun. 2014, 50, 2883. (t) Mori, K.; Wakazawa, M.; Akiyama, T. Chem. Sci. 2014, 5, 1799. (u) Osorio-Planes, L.; Rodriguez-Escrich, C.; Pericas, M. A. Chem. Eur. J. 2014, 20, 2367. (v) Terada, M.; Komuro, T.; Toda, Y.; Korenaga, T. J. Am. Chem. Soc. 2014, 136, 7044. (x) Tian, X.; Hofmann, N.; Melchiorre, P. Angew. Chem. Int. Ed. 2014, 53, 2997. (y) Wilent, J.; Petersen, K. S. J. Org. Chem. 2014, 79, 2303. (w) Cai, X.-F.; Guo, R.-N.; Feng, G.-S.; Wiu, B.; Zhou, Y.-G. Org. Lett. 2014, 16, 2680. (z) Zhang, Y.; Lim, C. S.; Sim, D. S. B.; Pan, H. J.; Zhao, Y. Angew. Chem. Int. Ed. 2014, 53, 1399.

(6) Enders, D.; Ludwig, M.; Raabe, G. Chirality 2012, 24, 215.

(7) (a) Stemper, J.; Isaac, K.; Duret, V.; Retailleau, P.; Voituriez, A.; Betzer, J.-F.; Marinetti, A. Chem. Commun. 2013, 49, 6084. (b) Stemper, J.; Isaac, K.; Pastor, J.; Frison, G.; Retailleau, P.; Voituriez, A.; Betzer, J.-F.; Marinetti, A. Adv. Synth. Catal. 2013, 355, 3613.

(8) The ring strain energies have been calculated from isodesmic exchange reactions on the Binol-derived acid, as in ref. $7 \mathrm{~b}$.

(9) Kabir, S. M. H.; Iyoda, M. Synthesis 2000, 1839.

(10) Selepe, M. A.; Drewes, S. E.; van Heerden, F. R. J. Nat. Prod. 2010, 73, 1680.

(11) (a) Lunazzi, L.; Mancinelli, M.; Mazzanti, A. J. Org. Chem. 2008, 73, 2198. (b) Harvey, P. D.; Brégier, F.; Aly, S. M.; Szmytkowski, J.; Paige, M. F.; Steer, R. P. Chem. Eur. J. 2013, 19, 4352.

(12) Grubbs, R. A.; Lewis, M. M.; Owens-Vance, C.; Gay, E. A.; Jassen, A. K.; Mailman, R. B.; Nichols, D. E. Bioorg. Med. Chem. 2004, 12, 1403.

(13) Isaac, K.; Stemper, J.; Retailleau, P.; Betzer, J.-F.; Marinetti, A. Eur. J. Org. Chem. 2014, 4099.

(14) The stereochemical description follows the Cahn-Ingold-Prelog nomenclature (R. S. Cahn, R.S.; Ingold, C.; Prelog, V. Angew. Chem. Int. Ed., 1966, 5, 385) with the aryl ring as the reference plane and $\mathrm{P}$ as the pilot atom.

(15) Kaupmees, K.; Tolstoluzhsky, N.; Raj, S.; Rueping, M.; Leito, I. Angew. Chem. Int. Ed. 2013, 52, 11569.

(16) For the synthesis of compounds 11 and 12, see Experimental Section.

(17) (a) Rueping, M.; Antonchick, A. P.; Theissmann, T. Angew. Chem. Int. Ed. 2006, 45, 3683. (b) Rueping, M.; Sugiono, E.; Schoepke, F. R. Synlett 2010, 852. (c) Zheng, C.; You, S.-L. Chem. Soc. Rev. 2012, 41, 2498.

(18) Chen, Q.-A.; Gao, K.; Dun, Y.; Ye, Z.-S.; Shi, L.; Yang, Y.; Zhou, Y.-G. J. Am. Chem. Soc. 2012, 134, 2442.

(19) Frisch, M. J.; Trucks, G. W.; Schlegel, H. B.; Scuseria, G. E.; Robb, M. A.; Cheeseman, J. R.; Scalmani, G.; Barone, V.; Mennucci, B.; Petersson, G. A.; Nakatsuji, H.; Caricato, 
M.; Li, X.; Hratchian, H. P.; Izmaylov, A. F.; Bloino, J.; Zheng, G.; Sonnenberg, J. L.; Hada, M.; Ehara, M.; Toyota, K.; Fukuda, R.; Hasegawa, J.; Ishida, M.; Nakajima, T.; Honda, Y.; Kitao, O.; Nakai, H.; Vreven, T.; Montgomery, J. A. J.; Peralta, J. E.; Ogliaro, F.; Bearpark, M.; Heyd, J. J.; Brothers, E.; Kudin, K. N.; Staroverov, V. N.; Keith, T.; Kobayashi, R.; Normand, J.; Raghavachari, K.; Rendell, A.; Burant, J. C.; Iyengar, S. S.; Tomasi, J.; Cossi, M.; Rega, N.; Millam, J. M.; Klene, M.; Knox, J. E.; Cross, J. B.; Bakken, C. Adamo, J. Jaramillo, R. Gomperts, R. E. Stratmann, O. Yazyev, A. J. Austin, R. Cammi, V.; Pomelli, C.; Ochterski, J. W.; Martin, R. L.; Morokuma, K.; Zakrzewski, V. G.; Voth, G. A.; Salvador, P.; Dannenberg, J. J.; Dapprich, S.; Daniels, A. D.; Farkas, O.; Foresman, J. B.; Ortiz, J. V.; Cioslowski, J.; Fox, D. J. Gaussian 09, revision B.01, 2010, Gaussian Inc., Wallingford, CT.

(20) Y. Zhao, D. G. Truhlar, Theor. Chem. Account 2008, 120, 215. 